\title{
Artikel
}

\section{Het Europees Openbaar Ministerie in de Nederlandse rechtsorde}

\author{
Mr. M.J. (Matthias) Borgers*
}

\section{NTS 2021/75}

\section{Inleiding}

Op 1 juni 2021 is het Europees Openbaar Ministerie (hierna: EOM) operationeel geworden. De strafrechtelijke bestrijding van strafbare feiten die de financiële belangen van de Unie schaden, ligt daarmee niet langer alleen in handen van de nationale autoriteiten, maar kan ook door deze nieuwe instelling van de Europese Unie plaatsvinden. Hoewel de oprichting van het EOM veel voeten in de aarde heeft gehad - de eerste voorstellen voor een EOM stammen al uit de jaren negentig van de vorige eeuw - en de deelname van Nederland aan het EOM lange tijd omstreden en onzeker is geweest, is het operationeel worden van het EOM in Nederland min of meer geruisloos verlopen. Niettemin heeft hiermee een fundamentele wijziging van één van de uitgangspunten van het Nederlandse strafprocesrecht plaatsgevonden: in het vervolgingsmonopolie van het Nederlandse openbaar ministerie is (opnieuw) een bres geslagen. Van oudsher geldt dat alleen het openbaar ministerie, zoals bedoeld in hoofdstuk 4 van de Wet RO, bevoegd is tot vervolging over te gaan. Hierop is eerder al in het kader van de strafbeschikking een specifieke en beperkte uit-

Mr. M.J. (Matthias) Borgers is raadsheer in de Hoge Raad der Nederlanden. Deze bijdrage is op persoonlijke titel geschreven. zondering aanvaard. ${ }^{1} \mathrm{Nu}$ is onder omstandigheden ook het EOM, een organisatie van de Europese Unie die losstaat van het Nederlandse openbaar ministerie, bevoegd om een verdachte te vervolgen én voor de Nederlandse rechter te brengen. Van een vervolgingsmonopolie van het Nederlandse openbaar ministerie is dus geen sprake meer. Het vervolgingsrecht is veeleer een gedeelde bevoegdheid geworden.

Tot grote wijzigingen in het Nederlandse strafprocesrecht heeft de totstandkoming van het EOM niet geleid. In het Wetboek van Strafvordering komt men slechts op één plaats een verwijzing naar het EOM tegen. ${ }^{2} \mathrm{De}$ reden voor die verwijzing is dat bij een vervolging door het EOM voor de Nederlandse strafrechter een gedelegeerde Europese aanklager optreedt die tevens aan het Nederlandse openbaar ministerie is verbonden. Het optreden van de gedelegeerde Europese aanklager valt weliswaar onder de verantwoordelijkheid van het EOM, maar deze aanklager heeft in de strafzaak alle bevoegdheden van een lid van het Nederlandse openbaar ministerie. Deze constructie, waarbij voor het optreden van het EOM in de deelnemende lidstaten gebruik wordt gemaakt van de bestaande juridische infrastructuur, heeft - ogenschijnlijk - de charme van de eenvoud. Niettemin is er wel regelgeving die in acht zal moeten worden genomen. Van belang is allereerst Verordening

1. Het gaat hierbij om de mogelijkheid van het uitvaardigen van een strafbeschikking - een daad van vervolging - door opsporingsambtenaren en door 'lichamen of personen, met een publieke taak belast'. Zie art. 257b lid 1 en 2 Sv en art. 257ba lid 1 Sv, en daarover G.J.M. Corstens, Het Nederlands strafprocesrecht, bewerkt door M.J. Borgers \& T. Kooijmans, Deventer: Wolters Kluwer 2021, p. 49, 639-640. Deze uitzondering is beperkt van aard omdat het uitvaardigen van een politiestrafbeschikking dan wel een bestuurlijke strafbeschikking plaatsvindt onder toezicht en volgens richtlijnen van het openbaar ministerie.

2. Art. 2 lid 3 Sv. Zie daarover par. 5.1 van deze bijdrage. 
(EU) 2017/1939 betreffende nauwere samenwerking bij de instelling van het Europees Openbaar Ministerie (hierna: de Verordening), ${ }^{3}$ waarin de Unierechtelijke regeling van het EOM is neergelegd. Voor deze verordening geldt, zoals voor elke verordening van de Europese Unie, ${ }^{4}$ dat deze niet in nationale wetgeving hoeft te worden omgezet en rechtstreekse werking heeft. Daarnaast is op 23 april 2021 de Invoeringswet EOM in werking getreden, die enkele wijzigingen in verschillende wetten heeft aangebracht met het oog op het optreden van het EOM in strafzaken die in Nederland worden berecht. $^{5}$

In deze bijdrage sta ik stil bij de vervolging van strafzaken door het EOM voor de Nederlandse strafrechter. ${ }^{6}$ Het is nog lastig aan te geven hoe vaak dit in de praktijk zal gebeuren. Maar als zo'n vervolging plaatsvindt in het Nederland, treedt de vraag naar voren of er verschillen of bijzonderheden bestaan in vergelijking met een 'gewone' strafzaak waarin het Nederlandse openbaar ministerie het vervolgingsrecht uitoefent en, zo ja, welke die zijn. Hiertoe ga ik allereerst op hoofdlijnen in op de organisatiestructuur van het EOM en de bevoegdheden van de daaraan verbonden aanklagers (par. 2) en op de afbakening van de bevoegdheden van het EOM en de nationale autoriteiten (par. 3). Daarna bespreek ik de situatie waarin het EOM besluit om een zaak niet te vervolgen; staat er een rechtsmiddel open tegen die beslissing (par. 4)? Vervolgens komt de vraag aan bod of en, zo ja, in welk opzicht, de vervolging van een strafzaak door het EOM voor de Nederlandse strafrechter bijzonderheden kent ten opzichte van een 'gewone' strafzaak (par. 5). De beschouwing in deze bijdrage is inventariserend en verkennend van aard. Er worden slechts enkele vragen besproken met betrekking tot de vervolging door het EOM, waarbij - zoals zal blijken - de antwoorden op die vragen niet steeds eenvoudig zijn te vinden.

\section{Een schets van het EOM en zijn bevoegdheden}

De organisatie van het EOM kent een centraal niveau en een decentraal niveau. ${ }^{7} \mathrm{Op}$ centraal niveau bestaat het EOM uit de Europese hoofdaanklager, de plaatsvervangend Europese hoofdaanklager en een college bestaande uit de Europese aanklagers van elk van de deelnemende

3. PbEU 2017, L 283/1.

4. Art. 288 VWEU: 'Een verordening heeft een algemene strekking. Zij is verbindend in al haar onderdelen en is rechtstreeks toepasselijk in elke lidstaat.'

5. Stb. 2021, 155. Zie over deze wet ook W. Geelhoed, 'De opsporingsen vervolgingscompetentie van het Europees Openbaar Ministerie in Nederland', Tijdschrift voor Bijzonder Strafrecht \& Handhaving 2020, p. 290-296.

6. De wijze waarop het (opsporings)onderzoek door het EOM verloopt, blijft grotendeels buiten beschouwing. Zie daarover nader Geelhoed 2020.

7. De tekst van deze paragraaf is grotendeels ontleend aan Corstens/ Borgers \& Kooijmans 2021, p. 128-130. lidstaten. ${ }^{8}$ Deze functionarissen vormen tevens meerdere permanente kamers die toezicht houden op het onderzoek en de vervolging en daarover de nodige beslissingen nemen. ${ }^{9}$ Die Europese aanklagers staan in verbinding met gedelegeerde Europese aanklagers in de eigen lidstaat, die belast zijn met de opsporing en vervolging van strafbare feiten die vallen binnen de bevoegdheid van het Europees Openbaar Ministerie. Elke deelnemende lidstaat heeft ten minste twee gedelegeerde Europese aanklagers. ${ }^{10}$ Deze gedelegeerde Europese aanklagers die de zaken van het EOM voor de nationale rechter brengen, vormen het decentrale niveau van het EOM. Zij blijven lid van het nationale openbaar ministerie en mogen ook nog 'gewone' nationale zaken doen, maar de werkzaamheden voor het EOM voeren zij in onafhankelijkheid van het nationale openbaar ministerie uit. ${ }^{11}$

De taak van het EOM is de bestrijding van strafbare feiten die de financiële belangen van de Unie schaden. De daadwerkelijke vervolging van die feiten moet door de gedelegeerde Europese aanklagers plaatsvinden voor de nationale gerechten. ${ }^{12}$ Het EOM is bevoegd ten aanzien van de strafbare feiten die zijn omschreven in Richtlijn 2017/1371, die betrekking heeft op de strafrechtelijke bestrijding van fraude die de financiële belangen van de Unie schaadt. ${ }^{13}$ Kort gezegd gaat het daarbij om fraude met EU-subsidies, invoerrechten en omzetbelasting. De vervolging van deze strafbare feiten vindt in beginsel door het EOM plaats. Zo nodig kan het EOM, wanneer nationale autoriteiten al een onderzoek zijn gestart, het onderzoek naar zich toe trekken door uitoefening van het zogenoemde evocatierecht. Dit evocatierecht houdt in dat het EOM de nationale autoriteiten kan opdragen om de behandeling van een dossier aan het EOM over te dragen, waarbij de nationale autoriteiten zich onthouden van verdere onderzoekshandelingen ten aanzien van dezelfde strafbare feiten. ${ }^{14}$ Ten aanzien van de strafbare feiten waarvoor het EOM bevoegd is, vinden het onderzoek en de vervolging plaats door de gedelegeerde Europese aanklager. Namens de betrokken permanente kamer oefent de Europese aanklager van de betreffende lidstaat toezicht uit op de werkzaamheden van de gedelegeerde Europese aanklagers. Het onderzoek kan door de gedelegeerde Europese aanklager zelf worden verricht, maar deze kan ook de bevoegde autoriteiten in zijn lidstaat daartoe opdracht geven. Dat onderzoek vindt plaats overeenkomstig het nationale recht van de lid-

8. Momenteel nemen 22 lidstaten van de Europese Unie deel. Voor Nederland is de Europese aanklager mr. D. Goudriaan.

9. Art. 8-12 Verordening.

10. Art. 13 lid 2 Verordening. Voor Nederland zijn als gedelegeerde Europese aanklagers aangewezen mr. P.P.A.M. Notenboom en mr. E. Visser.

11. Art. 13 Verordening.

12. Art. 4 Verordening.

13. PbEU 2017, L 198/29. Zie ook art. 22-23 Verordening.

14. Art. 27 lid 5 Verordening. In Kamerstukken / 2020/21, 35429, C, p. 11 wordt vermeld dat het evocatierecht niet meer kan worden uitgeoefend als de nationale autoriteiten op basis van het eigen onderzoek een tenlastelegging hebben uitgebracht, omdat dan de nationale rechter bevoegd is. Deze begrenzing in de tijd lijkt voort te vloeien uit art. 27 lid 7 Verordening. 
staat. ${ }^{15}$ Als het onderzoek is voltooid, brengt de gedelegeerde Europese aanklager zijn bevindingen over aan de Europese aanklager van zijn lidstaat, tezamen met een voorstel over de vervolging. De vervolgingsbeslissing wordt daarna genomen door de permanente kamer. De beslissing kan inhouden dat de zaak voor de rechter wordt vervolgd, op vereenvoudigde wijze wordt afgedaan of wordt geseponeerd. ${ }^{16}$ Aan deze beslissing wordt door de gedelegeerde Europese aanklager uitvoering gegeven.

Uit het vorenstaande volgt dat de werkzaamheden van het EOM op nationaal niveau bestaan uit de uitoefening van opsporingsbevoegdheden en dwangmiddelen onder gezag van een Nederlandse gedelegeerde Europese aanklager. Voor de toepassing van die bevoegdheden in Nederland gelden de Nederlandse strafvorderlijke voorschriften. Wanneer deze gedelegeerde Europese aanklager overgaat tot vervolging, verloopt ook de vervolging overeenkomstig de daarvoor in Nederland geldende voorschriften. De functie van gedelegeerd Europese aanklager wordt in Nederland vervuld door een officier van justitie die is verbonden aan het functioneel parket (art. 144c Wet RO). Wat betreft de feiten die worden vervolgd door de gedelegeerde Europese aanklager, zijn de bijzondere opsporingsdiensten bevoegd om onderzoek te verrichten (art. 3 Wet op de bijzondere opsporingsdiensten). ${ }^{17}$ Het EOM kent alleen (gedelegeerde) aanklagers en geen functionarissen die vergelijkbaar zijn met de advocaat-generaal bij het ressortsparket. Alle bevoegdheden die aan de officier van justitie, de advocaat-generaal en het openbaar ministerie toekomen - waaronder het optreden ter terechtzitting in hoger beroep - komen ten behoeve van de uitoefening van de taken van het Europees Openbaar Ministerie toe aan de Nederlandse (gedelegeerde) Europese aanklager (art. 144a en 144 b Wet RO). ${ }^{18}$

\section{Verdeling en afbakening van de bevoegdheid tot vervolging}

Het EOM is, zoals gezegd, bevoegd ten aanzien van de strafbare feiten die zijn omschreven in Richtlijn 2017/1371, die betrekking heeft op de strafrechtelijke bestrijding van fraude die de financiële belangen van de Unie schaadt. ${ }^{19}$ De regeling in de Verordening is echter

15. Art. 13 lid 1, 28 en 30-33 Verordening.

16. Art. $35-40$ Verordening. Een sepot is alleen mogelijk op basis van één van de in art. 39 lid 1 limitatief opgesomde gronden.

17. Vgl. daarover Geelhoed 2020, p. 292-293.

18. Vgl. Kamerstukken I/ 2019/20, 35429, nr. 3, p. 17. Zie ook artikel 13 lid 1 Verordening.

19. Daarbij gaat het om de in Richtlijn 2017/1371 bedoelde feiten 'zoals omgezet in het nationale recht, ongeacht of dezelfde strafbare gedraging naar nationaal recht als een ander strafbaar feit kan worden gekwalificeerd'. Zie art. 22 lid 1 Verordening. De verplichting tot omzetting in het nationale recht vloeit al voort uit de richtlijn. Die complex. ${ }^{20}$ In artikel 22 lid 1 Verordening worden de strafbare feiten die zijn omschreven in Richtlijn 2017/1371 tot uitgangspunt genomen: ten aanzien van die feiten is het EOM bevoegd om op te treden. Ten aanzien van sommige van die feiten geldt echter wel een nadere begrenzing: het moet dan gaan om opzettelijk handelen of nalaten dat betrekking heeft op het grondgebied van twee of meer lidstaten en er moet een totale schade van ten minste 10 miljoen euro mee zijn gemoeid. ${ }^{21}$ In artikel 22 lid 2 en 3 Verordening wordt het EOM ook bevoegd verklaard ten aanzien van, kort gezegd, deelname aan een criminele organisatie als de activiteiten van die organisatie het plegen van de strafbare feiten inhouden die zijn omschreven in Richtlijn 2017/1371, alsmede ten aanzien van andere strafbare feiten die onlosmakelijk verbonden zijn met de strafbare feiten die in die Richtlijn zijn omschreven. In het vierde lid van artikel 22 Verordening worden van de bevoegdheid van het EOM weer uitgezonderd strafbare feiten met betrekking tot nationale directe belastingen en daarmee onlosmakelijk verbonden strafbare feiten. Staat vast dat op grond van artikel 22 Verordening een strafbaar feit onder de bevoegdheid van het EOM valt, dan moet nog worden voldaan aan de vereisten van artikel 23 Verordening met betrekking tot territorialiteit en rechtsmacht.

De competentie van het EOM is niet exclusief; de nationale autoriteiten verliezen niet hun competentie om een strafbaar feit te vervolgen als het EOM bevoegd is om het betreffende feit te vervolgen. Wel geldt dat de nationale autoriteiten hun bevoegdheid niet uitoefenen als het EOM zelf een onderzoek instelt of wanneer het EOM gebruikmaakt van het evocatierecht. ${ }^{22}$ Het hier geschetste stelsel vergt vanzelfsprekend de nodige afstemming tussen het EOM en de nationale autoriteiten. De Verordening voorziet in een ruime hoeveelheid voorschriften die betrekking hebben op de melding aan het EOM van strafbare feiten die (mogelijk) onder de bevoegdheid van het EOM vallen, en van onderzoeken daarnaar door nationale instanties, op de registratie daarvan door het EOM en op de controle door het EOM of er aanleiding is om zelf een onderzoek in te stellen dan wel het evocatierecht uit te oefenen. ${ }^{23}$ Daarbij verschaft de Verordening ook nadere voorschriften in welke gevallen, ook al valt een feit onder de bevoegdheid van het EOM, het optreden aan de nationale autoriteiten wordt overgelaten. ${ }^{24}$

Vanzelfsprekend zullen er in de praktijk discussies kunnen ontstaan tussen de nationale autoriteiten en het EOM of een bepaald feit valt onder de bevoegdheid van

omzetting is voor het optreden van het EOM ook noodzakelijk omdat daarzonder vervolging van dat feit in de betreffende lidstaat niet mogelijk is.

20. Zie ook Geelhoed 2020, p. 291-292.

21. Het betreft daarbij de feiten als bedoeld in art. 3 lid 2 onder $d$ Richtlijn 2017/1371 (kort gezegd: btw-fraude).

22. Art. 25 lid 1 Verordening.

23. Art. 24 Verordening.

24. Art. 25 Verordening. 
het EOM en, zo dat het geval is, of het EOM ook de aangewezen instantie is om het onderzoek en de vervolging op zich te nemen. In dit verband voorziet artikel 25 lid 6 Verordening in een regeling die ertoe strekt dat de nationale autoriteiten het laatste woord hebben. Die regeling is echter niet allesomvattend. ${ }^{25}$ Deze ziet bijvoorbeeld niet op de situatie waarin discussie bestaat of een feit zich al dan niet laat kwalificeren als een strafbaar feit zoals omschreven in Richtlijn 2017/1371, ${ }^{26}$ terwijl ook anderszins interpretatie- en uitwerkingsvragen mogelijk zijn ten aanzien van deze regeling. ${ }^{27}$ Op andere onderdelen schrijft de Verordening voor dat overleg moet plaatsvinden met de nationale autoriteiten of dat instemming van de nationale autoriteiten moet worden verkregen..$^{28}$ De exacte reikwijdte van deze regelingen kan in het midden blijven. Duidelijk is in ieder geval dat, ook al is dit niet tot in ieder detail geregeld, verschillen van inzicht over de bevoegdheid van het EOM om op te treden in een concrete zaak, zo veel mogelijk moeten worden opgelost in de verhouding tussen het EOM en de nationale autoriteiten.

De Verordening voorziet niet expliciet in rechterlijke geschilbeslechting bij conflicten over de bevoegdheid van het EOM. De Verordening sluit echter ook niet uit dat de rechter zich daarover wel zal moeten uitspreken. Op dit punt is van belang dat artikel 42 lid 2 Verordening bepaalt dat het Hof van Justitie bevoegd is bij wijze van prejudiciële beslissing uitspraak te doen over onder meer 'de uitlegging van artikel 22 en artikel 25 van deze verordening, met betrekking tot een bevoegdheidsconflict tussen het EOM en de bevoegde nationale autoriteiten'. Een dergelijke bevoegdheid heeft alleen betekenis wanneer de nationale rechter een beslissing zal moeten nemen waarvoor het al dan niet bevoegd zijn van het EOM om in een strafzaak op te treden (mede) een beslissende omstandigheid is. Als in zo'n geval niet duidelijk is hoe op grond van artikel 22 en 25 Verordening moet worden geoordeeld over die bevoegdheid, kan of moet het Hof van Justitie via een prejudiciële vraag worden betrokken. ${ }^{29}$ Welke omstandigheden ertoe kunnen leiden dat de nationale rechter wordt gevraagd zich uit te spreken over de bevoegdheid van het EOM, blijkt niet uit de Verordening. In het navolgende keert dit punt nog terug (zie par. 5.3).

In Kamerstukken I/ 2019/20, 35429, nr. 6, p. 20-21 wordt gesuggereerd dat dit wel het geval zou zijn.

26. De regeling van art. 25 lid 6 Verordening beperkt zich tot de vraag of sprake is van een feit als bedoeld in art. 22 lid 2 en 3 Verordening, en de vraag of art. 25 lid 3 Verordening noopt tot verwijzen van een zaak naar de nationale autoriteiten. De in de hoofdtekst genoemde vraag raakt juist aan het eerste lid van art. 22 Verordening.

27. Zie nader Geelhoed 2020, p. 293-295.

28. Zie art. 25 lid 2 (raadplegen) en lid 4 (instemming) Verordening.

29. Met betrekking tot de vraag of de nationale rechter gehouden is een prejudiciële vraag te stellen, zijn de bekende Cilfit-criteria van belang. Zie HvJ EU 6 oktober 1982, zaak C-283/81, ECLI:EU:C:1982:335.

\section{Niet-vervolging door het EOM}

\subsection{Totstandkoming en modaliteiten van de} vervolgingsbeslissing van het EOM

Als er onder verantwoordelijkheid van het EOM een onderzoek plaatsvindt, kunnen er op basis van de bevindingen van het onderzoek verschillende vervolgstappen worden gezet en beslissingen worden genomen. Allereerst kan er aanleiding bestaan om de zaak over te dragen aan de bevoegde nationale autoriteiten. In deze gevallen komt het niet tot het door het EOM aanbrengen van de zaak bij de strafrechter, het seponeren van de zaak of het vereenvoudigd afdoen van de zaak, maar is het aan de nationale autoriteiten om te beslissen of men zelf een onderzoek instelt. Artikel 34 Verordening regelt deze situaties. Het kan bijvoorbeeld gaan om het geval waarin het EOM vaststelt dat de onderzochte feiten en omstandigheden geen strafbaar feit opleveren dat binnen de bevoegdheid van het EOM valt. In sommige gevallen, waarbij de bevoegdheid van het EOM om het feit te onderzoeken en te vervolgen op zich niet in het geding is, kan de beslissing van de nationale autoriteiten om de zaak niet over te nemen, ertoe leiden dat het EOM alsnog een vervolgingsbeslissing neemt. ${ }^{30}$

In alle gevallen waarin het onderzoek door het EOM wordt afgerond (en geen grond of aanleiding bestaat voor overdracht aan de bevoegde nationale autoriteiten), stuurt de gedelegeerde Europese aanklager een verslag met een samenvatting van de zaak en een voorstel over de afdoening daarvan naar de toezichthoudende Europese aanklager, dat wil zeggen: de Europese aanklager van zijn of haar lidstaat. ${ }^{31}$ Deze toezichthoudende Europese aanklager stuurt, indien hij of zij dit nodig acht, de documenten samen met een eigen beoordeling naar de permanente kamer. Als de permanente kamer het voorstel van de gedelegeerde Europese aanklager overneemt, zet deze de zaak dienovereenkomstig voort. De permanente kamer kan ook tot een ander besluit komen of beslissen om nadere instructies aan de gedelegeerde Europese aanklager te geven. Deze procedure is neergelegd in artikel 35 Verordening.

Er kunnen drie beslissingen worden genomen. Allereerst kan de beslissing inhouden dat de zaak voor de rechter wordt vervolgd. De zaak wordt dan - zo nodig nadat is beslist in welke lidstaat de zaak voor de rechter wordt gebracht - vervolgd voor de rechter die volgens het nationale recht van de betreffende lidstaat bevoegd is. ${ }^{32}$ De tweede beslissing die kan worden genomen, betreft het seponeren van de zaak op grond van één van de in artikel 39 lid 1 Verordening limitatief omschreven sepotgronden. Op dit sepot kom ik zo dadelijk terug. De derde mogelijkheid is dat de strafzaak wordt afgedaan in een vereenvoudigde procedure. Deze laatste mogelijk-

30. Art. 34 lid 5 Verordening.

31. Vgl. art. 12 lid 1 Verordening.

32. Art. 36 lid 3 en 5 Verordening. 
heid bestaat alleen als 'de toepasselijke nationale wetgeving voorziet in een vereenvoudigde procedure waarmee de definitieve afdoening van een strafzaak wordt bereikt door het overeenkomen van voorwaarden met de verdachte' (art. 40 lid 1 Verordening). Aan de inzet van de vereenvoudigde procedure worden in artikel 40 Verordening enkele spelregels verbonden. De bewoordingen van deze bepalingen - in het bijzonder 'het overeenkomen van voorwaarden' - duiden erop dat het bij de vereenvoudigde procedure gaat om een consensuele afdoening. In de Nederlandse context denkt men dan vooral aan de transactie als de afdoeningswijze die het meest in de buurt komt van een consensuele afdoening. Ik zie echter geen beletsel om ook het voorwaardelijk sepot en het uitvaardigen van een strafbeschikking aan te merken als vereenvoudigde procedures. Weliswaar gaat het daarbij niet zozeer om het overeenkomen van voorwaarden, maar om zelfstandige wijzen van het afdoen van een strafzaak. Dat neemt niet weg dat de verdachte het tot op zekere hoogte in eigen hand heeft door al dan niet de gestelde voorwaarden na te leven of door al dan niet verzet in te stellen - of de zaak aan de rechter wordt voorgelegd. Naar het mij voorkomt, is er daarmee voldoende aanleiding om de transactie, het voorwaardelijk sepot en de strafbeschikking te scharen onder de regeling van artikel 40 Verordening.

Nadere aandacht verdient nog het sepot en in verbinding daarmee de beslissingsruimte die het EOM heeft om een zaak niet aan de rechter voor te leggen dan wel vereenvoudigd af te doen. In de preambule bij de Verordening wordt het volgende opgemerkt: ${ }^{33}$

'Met het oog op de rechtszekerheid en om doeltreffend op te treden tegen strafbare feiten die de financiele belangen van de Unie schaden, dienen de onderzoeks- en strafvervolgingsactiviteiten van het EOM gebaseerd te zijn op het legaliteitsbeginsel, waarbij het EOM de voorschriften van deze verordening strikt moet toepassen, met name de voorschriften inzake bevoegdheid en de uitoefening daarvan, de instelling en beëindiging van onderzoeken, de verwijzing van zaken, sepot, en vereenvoudigde strafvervolgingsprocedures.

(...)

Uitgaande van het legaliteitsbeginsel dienen de onderzoeken van het EOM in de regel te leiden tot strafvervolging voor de bevoegde nationale rechter wanneer er voldoende aanwijzingen zijn en er geen wettelijke gronden zijn aan die strafvervolging in de weg staan, en er evenmin een vereenvoudigde strafvervolgingsprocedure is gevolgd. De redenen voor het seponeren van een zaak zijn uitputtend in deze verordening opgesomd.'

Hier wordt heldere taal gesproken: leidend is het legaliteitsbeginsel en niet (een vorm van) het opportuniteitsbeginsel. De opsomming van sepotgronden in artikel 39

33. Preambule, onder 66 en 81. lid 1 Verordening sluit daarbij aan. Die gronden, die vanuit het Nederlandse perspectief overwegend als vervolgingsbeletsel zouden worden gezien, betreffen het overleden zijn van de verdachte (of het ontbonden zijn van de verdachte rechtspersoon), ontoerekeningsvatbaarheid van de verdachte, amnestie, immuniteit, verjaring, ne bis in idem en gebrek aan bewijsmateriaal. Dit stelsel duidt erop dat opportuniteitsoverwegingen niet aan de orde zijn. Al valt het dan wel op dat de hiervoor geciteerde tekst van de preambule - met de woorden 'in de regel' - enige ruimte laat om dergelijke overwegingen te betrekken.

Geelhoed noemt nog een andere reden waarom, niettegenstaande de expliciete verwijzing naar het legaliteitsbeginsel, ruimte zou bestaan voor het betrekken van opportuniteitsargumenten. Hij wijst erop dat de toezichthoudende Europese aanklager op grond van artikel 35 lid 1 Verordening het voorstel van de gedelegeerde Europese aanklager voor de afdoening van de zaak aan de permanente kamer voorlegt 'indien hij [de toezichthoudende Europese aanklager; MB] dit nodig acht'. ${ }^{34}$ Dat laat 'veel ruimte voor allerlei gezichtspunten die normaal gesproken bij de toepassing van het opportuniteitsbeginsel betrokken kunnen worden', aldus Geelhoed. ${ }^{35}$ Men kan echter de woorden 'indien hij dit nodig acht' ook anders uitleggen, namelijk in die zin dat deze niet méér betekenen dan dat de toezichthoudende Europese aanklager niet is gehouden om steeds de permanente kamer te betrekken, maar ook ruimte heeft om zelf te beslissen of het voorstel van de gedelegeerde Europese aanklager wordt gevolgd. Dan blijft de permanente kamer buiten beeld, maar daarmee is nog niet gezegd dat de gedelegeerde of de toezichthoudende Europese aanklager niet zou zijn gebonden aan de regeling van de sepotgronden in artikel 39 lid 1 Verordening. Wel kan erop worden gewezen dat in (de preambule bij) de Verordening meermalen wordt verwezen naar de noodzaak van een coherent, efficiënt en consistent vervolgingsbeleid. ${ }^{36}$ Zo'n beleid lijkt nauwelijks nodig als men kijkt naar de - op vervolgingsbeletselen lijkende - sepotgronden van artikel 39 lid 1 Verordening. ${ }^{37}$ Het is dus niet uitgesloten dat het EOM in de praktijk zich toch tot op zekere hoogte zal bedienen van opportuniteitsargumenten bij het nemen van de vervolgingsbeslissing.

De Verordening geeft niet expliciet een regeling met betrekking tot de status van een sepotbeslissing: staat deze eraan in de weg dat nadien alsnog door het EOM

34. Zie ook de preambule onder 78: 'De beslissing om de verdachte of beklaagde in staat van beschuldiging te stellen dient in beginsel te worden genomen door de bevoegde permanente kamer, op basis van een ontwerpbesluit van de gedelegeerd Europese aanklager, zodat er een gemeenschappelijk strafvervolgingsbeleid is.'

35. W. Geelhoed, 'Het Europees Openbaar Ministerie en het opportuniteitsbeginsel in Nederland', Strafblad 2018/54

36. Zie art. 9 lid 2 Verordening en de preambule onder 24, 36, 78 en 82.

37. Al zal dat beleid niet alleen hoeven te zien op de keuze om een strafbaar feit wel of niet te vervolgen, maar kan het zich ook uitstrekken over de vraag naar de verdeling van zaken tussen het EOM en bevoegde nationale autoriteiten. 
dan wel door de nationale autoriteiten tot vervolging wordt overgegaan ${ }^{38}$ Op grond van de Verordening kan echter wel een en ander hierover worden gezegd. Daarbij kan worden vooropgesteld dat bij de meeste sepotgronden het zich moeilijk laat denken dat alsnog zou worden vervolgd, bijvoorbeeld als het gaat om de dood van de verdachte (dan wel de ontbinding van de verdachte rechtspersoon), het ingetreden zijn van de verjaring of het eerder onherroepelijk zijn afgedaan van het feit. ${ }^{39}$ Waar het gaat om het sepot op de grond dat er gebrek aan bewijsmateriaal is, bepaalt artikel 39 lid 2 Verordening dat dit sepot geen belemmering is voor verder onderzoek 'op basis van nieuwe feiten die bij het EOM niet bekend waren op het tijdstip van het besluit en bekend zijn geworden nadat het besluit is genomen'. Zonder dergelijke nieuwe feiten blijft - zo kan hieruit worden afgeleid - een nieuw onderzoek achterwege. Aangenomen mag worden dat, als het op basis van nieuwe feiten komt tot heropening van het onderzoek, eerst na afronding van dat onderzoek opnieuw een vervolgingsbeslissing door het EOM mag worden genomen. Van belang is hier ook de regeling van artikel 34 lid 6 en artikel 39 lid 3 Verordening. Waar het gaat om andere strafbare feiten die onlosmakelijk zijn verbonden met gedragingen die onder de reikwijdte van Richtlijn 2017/1371 vallen, geldt dat een sepot pas mogelijk is na overleg met nationale autoriteiten van de lidstaat. Als bij dit overleg blijkt dat de nationale autoriteit verlangt dat de zaak naar die autoriteit wordt verwezen, is het EOM gehouden het dossier over te dragen en ziet het af van verdere onderzoeks- en vervolgingsmaatregelen. Een vergelijkbare regeling bestaat voor de situatie waarin het onderzoek van het EOM zich heeft gericht op bepaalde strafbare feiten en waarbij is gebleken dat de schade aan de financiële belangen van de Unie niet hoger is of zal zijn dan de schade van een ander slachtoffer. Ik begrijp deze regelingen zo dat het in deze situaties niet tot een sepot door het EOM komt als de nationale autoriteit verwijzing van de zaak verlangt, en dat daardoor de betreffende nationale autoriteit de mogelijkheid behoudt om de zaak zelf verder te onderzoeken en te vervolgen. Deze regeling is kennelijk nodig omdat als er wél een sepotbeslissing door het EOM zou worden genomen, dat sepot ook in de weg zou staan aan nader onderzoek en vervolging door de nationale autoriteiten. Een en ander wijst er dus op dat na een sepot in de zin van artikel 39 Verordening het betreffende strafbare feit niet alsnog kan worden vervolgd, behoudens het naar voren treden van nieuwe feiten, en dat de sepotbeslissing van het EOM niet alleen het EOM maar ook de nationale autoriteiten bindt.

38. Vgl. Y. de Vries \& S.J. Lopik, 'Het Europees Openbaar Ministerie komt eraan: waakhond of papieren tijger?', NtER 2019, p. 109, die vanwege het ontbreken van een specifieke bepaling op dit punt het onduidelijk achten of het ne bis in idem-beginsel in de weg staat aan vervolging na een sepot.

39. Waar het gaat om het genieten van immuniteit van de verdachte, zou kunnen worden gedacht aan de situatie dat na het sepot die immuniteit wordt opgeheven.
4.2 Toetsing van de beslissing van het EOM om niet te vervolgen door de Nederlandse rechter?

Het is niet uitgesloten dat de beslissing van het EOM om een zaak te seponeren op bezwaren stuit. Dat kan bijvoorbeeld het geval zijn als het gaat om een feit dat niet alleen de financiële belangen van de Unie heeft aangetast, maar ook dat van anderen. Ook zou de situatie zich kunnen voordoen dat na een door het EOM uitgevoerd (opsporings)onderzoek, een vervolgingsbeslissing achterwege blijft. Kan een belanghebbende dan klagen over de sepotbeslissing van het EOM of over het uitblijven van een vervolgingsbeslissing? Anders gezegd: is de beslissing van het EOM om niet tot vervolging over te gaan dan wel het nalaten een vervolgingsbeslissing te nemen, toetsbaar door de rechter en, zo ja, om welke rechter gaat het dan? ${ }^{40}$ In dit verband is de regeling van artikel 42 Verordening van belang. Het eerste lid van artikel 42 Verordening bepaalt het volgende:

'Procedurele handelingen van het EOM die bedoeld zijn om rechtsgevolgen ten aanzien van derden te creeren, moeten worden getoetst door de bevoegde nationale rechter overeenkomstig de voorschriften en procedures in het nationale recht. Hetzelfde geldt wanneer het EOM nalaat procedurele handelingen vast te stellen die bedoeld zijn om rechtsgevolgen ten aanzien van derden te creëren, wanneer het in het kader van deze verordening wettelijk verplicht is om deze vast te stellen.'

Dit biedt een helder uitgangspunt, op grond waarvan zou kunnen worden aangenomen dat het beklag van artikel $12 \mathrm{~Sv}$ zich ook uitstrekt tot de vervolgingsbeslissing in zaken waarin een Nederlandse gedelegeerde Europese aanklager is betrokken. Het derde lid van artikel 42 Verordening houdt echter in dat, in afwijking van het eerste lid van die bepaling, besluiten van het EOM om een zaak te seponeren, voor zover deze rechtstreeks op basis van het Unierecht wordt aangevochten, voor het Hof van Justitie worden getoetst overeenkomstig artikel 263 lid 4 VWEU (Verdrag betreffende de werking van de Europese Unie). Laatstgenoemd voorschrift ziet daarbij op het door een natuurlijke persoon of een rechtspersoon instellen van beroep instellen tegen handelingen van een instelling van de Unie die tot hem gericht zijn of die hem rechtstreeks en individueel raken. Dat beroep wordt ingesteld bij het Hof van Justitie.

Dit samenstel van bepalingen roept vragen op. Allereerst lijkt artikel 42 lid 3 Verordening met de woorden 'in afwijking van het eerste lid' de toetsingsbevoegdheid van de nationale rechter te beperken, in die zin dat deze zich niet mag uitspreken over een sepotbeslissing als

40. Zie over deze vragen ook W. Geelhoed, 'Rechterlijke toetsing van Europese vervolgingsbeslissingen, in het bijzonder het gelijkheidsbeginsel', in: B. Leeuw e.a. (red.), Leidse gedachten voor een modern straf(proces)recht, Den Haag: BJu 2017, p. 89-107 en M. de Meijer, 'Beklagrecht in geval van niet-vervolging door het Europese $O M^{\prime}$ ', in: D. de Wolff, Toegang tot het recht, Den Haag: BJu 2019, p. 67-79. 
deze rechtstreeks op basis van het Unierecht wordt aangevochten. ${ }^{41}$ Of mogen de woorden 'in afwijking van het eerste lid' misschien zo worden opgevat dat het uitgangspunt van het eerste lid - toetsing door de nationale rechter - niet in de weg staat aan een beroep op grond van artikel 263 lid 4 VWEU bij het Hof van Justitie? Zo bezien zou de procedure bij het Hof van Justitie een vangnet kunnen vormen in die gevallen waarin het nationale recht niet voorziet in een beklagprocedure zoals Nederland die kent met de regeling van artikel 12 $\mathrm{Sv}^{42}$ Een vergelijkbaar discussiepunt speelt met betrekking tot de clausule 'voor zover deze rechtstreeks op basis van het Unierecht wordt aangevochten' in artikel 42 lid 3 Verordening. Op zichzelf is het logisch dat als een sepotbeslissing van het EOM bij het Hof van Justitie wordt aangevochten, uitsluitend het Unierecht kan worden ingeroepen. Het Hof van Justitie past immers geen nationaal recht toe. Dat betekent echter niet dat bezwaren van Unierechtelijke aard alleen voor het Hof van Justitie zouden kunnen worden aangevoerd. Integendeel, op het moment dat een sepotbeslissing van het EOM voor de nationale rechter wordt aangevochten, vormt (in elk geval) artikel 39 Verordening - de regeling van de sepotgronden die het EOM kan toepassen - het relevante toetsingskader. Uit de Verordening blijkt ook niet dat er een beletsel zou bestaan voor de nationale rechter om de sepotbeslissing van het EOM aan het Unierecht te toetsen. Integendeel, voor die toetsing is juist het Unierecht - en dan in het bijzonder het stelsel van sepotgronden in artikel 39 Verordening - van belang. Het tweede lid van artikel 42 Verordening expliciteert daarbij dat de nationale rechter prejudiciële vragen kan stellen over onder meer de geldigheid van procedurele handelingen van het EOM op grond van het Unierecht en over de uitleg van bepalingen van de Verordening.

Op grond van het vorenstaande kom ik voorzichtig tot de slotsom dat gelet op artikel 42 Verordening een sepotbeslissing van het EOM, het uitblijven van een vervolgingsbeslissing door het $\mathrm{EOM},{ }^{43}$ dan wel de keuze

41. Vgl. in deze zin De Vries \& Lopik 2019, p. 109.

42. Vgl. Geelhoed 2017, p. 91 en 94, die ten aanzien van (een voorloper van) art. 42 lid 3 Verordening opmerkt: 'Het gaat hierbij vooral om beslissingen waarbij niet in alle lidstaten is voorzien in een rechterlijke toetsingsmogelijkheid, bijvoorbeeld sepotbeslissingen.' In het oorspronkelijke ontwerp van de Verordening werd de rechterlijke toetsing volledig op nationaal niveau gelegd. Vgl. daarover A. Meij, 'Some explorations into the EPPO's administrative structure and judicial review', in: L.H. Erkelens e.a. (red.), The European Public Prosecutor's Office, Den Haag: Asser Press 2015, p. 101-119.

43. Spiegelbeeldig kan nog worden gewezen op de vraag of stilzitten door het EOM ook ertoe kan leiden dat op verzoek van de verdachte een verklaring wordt gegeven dat de zaak is geëindigd (art. 29f Sv). Art. 42 lid 1 Verordening lijkt ook die vorm van rechterlijke interventie toe te staan, in aanmerking genomen dat het EOM na afronding van een onderzoek is gehouden tot het nemen van een beslissing over het vervolg van de zaak. $\mathrm{Vgl}$. in dit verband de preambule onder 87: 'Als gerechtelijke stappen bij bevoegde nationale rechtbanken wegens stilzitten van het EOM worden beschouwd, de stappen met betrekking tot procedurele handelingen die het EOM wettelijk verplicht is vast te stellen, en die bedoeld zijn om rechtsgevolgen ten aanzien van derden te creëren.' voor vereenvoudigde afdoening door middel van het opleggen van een strafbeschikking voorwerp kan zijn van een beklag in de zin van artikel $12 . \mathrm{Sv}^{44}$ Wanneer dat beklag wordt gedaan, verloopt die procedure op de gebruikelijke wijze. Maar er kunnen ook bijzonderheden worden angewezen. Ik stip er enkele aan. Allereerst is er de vraag welk gerecht bevoegd is om het beklag te behandelen. Artikel 12 lid $1 \mathrm{~Sv}$ wijst het hof Den Haag aan voor zaken waarin de beslissing is genomen door een officier van justitie bij het functioneel parket. In relatie tot het EOM kan bij deze bepaling aansluiting worden gezocht. Weliswaar treedt de gedelegeerde Europese aanklager in een EOM-zaak op namens het EOM en niet als lid van het Nederlandse openbaar ministerie, de wetgever heeft gekozen voor een stelsel waarin de gedelegeerde Europese aanklagers zijn verbonden aan het functioneel parket (art. 144c Wet RO). Ook wat betreft de rechtbanken waar EOM-zaken kunnen worden vervolgd heeft de wetgever aansluiting gezocht bij de competentieregeling voor EOM-zaken (zie par. 5.1). Ten tweede is van belang dat in de beklagprocedure, nu deze voor een gerechtshof plaatsvindt, een advocaat-generaal optreedt. Het ligt echter niet voor de hand dat een lid van het Nederlandse openbaar ministerie in de beklagprocedure optreedt voor het EOM. Dat is ook niet nodig, omdat aan de gedelegeerde Europese aanklager ook alle bevoegdheden toekomen die naar Nederlands recht toekomen aan de advocaat-generaal (art. 144a lid 1 Wet RO). De gedelegeerde Europese aanklager kan dus optreden in de beklagprocedure en op die wijze de belangen van het EOM behartigen. Mede in aanmerking genomen dat er in Nederland (vooralsnog) slechts twee gedelegeerde Europese aanklagers zijn, betekent dit wel dat de situatie zich eenvoudig kan voordoen dat de aanklager die optreedt in de beklagprocedure ${ }^{45}$ ook mede betrokken is geweest bij het voorbereiden en nemen van de vervolgingsbeslissing. Dit terwijl de 'reguliere' beklagprocedure zich kenmerkt door het optreden van een lid van het openbaar ministerie die enige distantie heeft van de genomen vervolgingsbeslissing. ${ }^{46}$ Ten derde is er de vraag op welke wijze de beklagrechter de beslissing van het EOM toetst. Uitgangspunt in de artikel $12 \mathrm{~Sv}$-procedure is dat de rechter de opportuniteit van de vervolging een rol mag laten spelen. Artikel 12i Sv bepaalt immers dat het hof het geven van een bevel tot (verdere) vervolging kan weigeren op gronden aan het algemeen belang ontleend. Zoals hiervoor aan de orde is gekomen, kent de Verordening een limitatieve opsomming van sepotgronden en is voor het EOM het legaliteitsbeginsel leidend. Daarmee verhoudt zich niet

44. In Kamerstukken // 2019/20, 35429, nr. 6, p. 12 wordt eveneens aangenomen dat de procedure van art. 12 Sv kan worden toegepast, maar daaraan wordt toegevoegd dat in veel gevallen van niet verdere vervolging de zaak eerst terugkomt bij de nationale autoriteiten en dat dan alsnog vervolging kan volgen. Dit laatste is echter alleen het geval als de zaak, zoals in par. 4.1 is besproken, aan de nationale autoriteiten wordt overgedragen. In zo'n geval komt het niet tot een vervolgingsbeslissing van het EOM en dus ook niet tot een sepot door het EOM.

45. En die dus het schriftelijk verslag als bedoeld in art. 12a lid 2 Sv opstelt.

46. Al zou het niet onmogelijk zijn dat de zaaksofficier van justitie optreedt als plaatsvervangend advocaat-generaal in de beklagprocedure. 
goed dat in een beklagprocedure het opportuniteitsbeginsel tot uitgangspunt wordt genomen. Aan de orde is echter ook gekomen dat het niet uitgesloten lijkt dat het EOM in de praktijk zich toch tot op zekere hoogte zal bedienen van opportuniteitsargumenten bij het nemen van de vervolgingsbeslissing. Het ligt in de rede dat de beklagrechter zich bij de toetsing richt op het stelsel van sepotgronden in de Verordening en op het vervolgingsbeleid van het EOM zoals zich dat zal ontwikkelen. Tot slot wijs ik nog op de regeling van de zogeheten bewilliging. Als het openbaar ministerie na een bevel tot (verdere) vervolging een kennisgeving van niet-verdere vervolging wil uitdoen, is dat alleen mogelijk als het hof daarin bewilligt (art. 243 lid $5 \mathrm{~Sv}$ ). Het is niet duidelijk of deze regeling ook geldt als het bevel is gericht tot het EOM. Een contra-indicatie daarvoor is wellicht dat de vervolgingsbeslissing van het EOM op zichzelf wordt beheerst door de Verordening en niet door het Wetboek van Strafvordering. Daar kan echter tegenover worden gesteld dat artikel 42 lid 3 Verordening spreekt van toetsing door de nationale rechter 'overeenkomstig de voorschriften en procedures in het nationale recht', waarbij er dan op kan worden gewezen dat het voorschrift van artikel 243 lid $5 \mathrm{~Sv}$ nauw samenhangt met de regeling van artikel $12 \mathrm{~Sv}$.

\section{Vervolging door het EOM}

\subsection{Competentie van de rechter}

Vervolging door het EOM houdt in dat een gedelegeerde Europese aanklager een zaak voor de nationale strafrechter brengt. ${ }^{47}$ Deze vervolging heeft in principe op dezelfde wijze plaats als een 'gewone' nationale strafzaak. In Nederland zal de gedelegeerde Europese aanklager, die tevens een Nederlandse officier van justitie is, de zaak ter terechtzitting aanhangig maken door een dagvaarding uit te brengen. Omdat de vervolging daarbij betrekking heeft op een strafbaar feit dat - overeenkomstig Richtlijn 2017/1371 - naar nationaal recht strafbaar is gesteld, zijn daarbij de reguliere regels met betrekking tot de absolute en relatieve competentie van de rechter van toepassing. ${ }^{48}$ De Invoeringswet EOM heeft niettemin voorzien in één specifiek voorschrift. Op grond van artikel 2 lid $3 \mathrm{~Sv}$ geldt dat de rechtbanken Amsterdam, Oost-Brabant, Overijssel en Rotterdam bevoegd zijn tot kennisneming in eerste aanleg van de strafbare feiten die op grond van de Verordening worden vervolgd. Deze regeling sluit nauw aan bij artikel 2 lid $1 \mathrm{~Sv}$, waarin dezelfde rechtbanken zijn aangewezen als de bevoegde rechtbanken voor zaken waarmee de officier van justitie bij het functioneel parket is belast. ${ }^{49}$

47. Vgl. art. 36 Verordening

48. Zie art. 36 lid 5 Verordening: 'Wanneer beslist is in welke lidstaat de strafvervolging zal geschieden, bepaalt het nationale recht welke de bevoegde nationale rechtbank is.'

49. Voor zover het gaat om feiten die zijn genoemd in art. 2 Besluit regels landelijk parket en functioneel parket, alsmede ten aanzien van mandateren bevoegdheden officier van justitie.
De achterliggende reden is, zoals hierboven naar voren kwam, dat de voor Nederland aangestelde gedelegeerde Europese aanklagers (tevens) zijn verbonden aan het functioneel parket. ${ }^{50}$

De tekst van artikel 2 lid $3 \mathrm{~Sv}$ duidt erop dat de rechtbanken Amsterdam, Oost-Brabant, Overijssel en Rotterdam bij uitsluiting bevoegd zijn tot kennisneming in eerste aanleg van de strafbare feiten die op grond van de Verordening worden vervolgd. De wetgever heeft er immers niet voor gekozen om deze bepaling van relatieve competentie op te nemen in de opsomming van artikel 2 lid $1 \mathrm{~Sv}$ van rechtbanken die 'gelijkelijk' bevoegd zijn om van bepaalde strafbare feiten kennis te nemen, en waarvoor het tweede lid van artikel $2 \mathrm{~Sv}$ een conflictregel geeft voor het geval dat gelijktijdig wordt vervolgd bij meer dan één rechtbank. Ik begrijp het wettelijke stelsel daarom zo dat als de vervolging plaatsvindt door het EOM, dat dan (uitsluitend) artikel 2 lid $3 \mathrm{~Sv}$ regelt welke rechtbanken relatief competent zijn. ${ }^{51}$ Gaat het om een strafbaar feit waarvoor het EOM op zich wel bevoegd is om te vervolgen, maar waarbij het EOM geen gebruik makt van die bevoegdheid en de vervolging overlaat aan de nationale autoriteiten, dan geldt bij vervolging door het Nederlandse openbaar ministerie dat artikel 2 lid 1 en $2 \mathrm{~Sv}$ de relatieve competentie van de rechtbank bepaalt. Het is de vraag of deze kwestie van groot praktisch belang is, want het is heel goed denkbaar dat men bij dezelfde rechtbank uitkomt. ${ }^{52}$ Dat neemt niet weg dat de regeling van artikel 2 lid 1 en $2 \mathrm{~Sv}$ op zich de ruimte laat om bij een andere rechtbank dan Amsterdam, Oost-Brabant, Overijssel of Rotterdam uit te komen. ${ }^{53}$ Het is daarom van belang dat er geen onduidelijkheid bestaat wie er als vervolgende instantie optreedt: het EOM of het Nederlandse openbaar ministerie. Omdat de gedelegeerde Europese aanklager aan beide instituten is verbonden, zal deze duidelijk moeten laten zien met welke pet op de vervolging wordt ingesteld. Hij kan in een concrete zaak niet namens beide instituten tegelijkertijd optreden, maar vervult óf de functie van gedelegeerde Europese aanklager óf de functie van officier van justitie bij het functioneel parket. ${ }^{54}$

50. Kamerstukken I/ 2019/20, 35429, nr. 3, p. 7, 16.

51. Vgl. Kamerstukken // 2019/20, 35429, nr. 3, p. 7.

52. Het functioneel parket is immers belast met de vervolging van de feiten waarvoor ook het Europees Openbaar Ministerie bevoegd is. Dit vloeit voort uit art. 9 lid 3 Sv en art. 2 Besluit regels landelijk parket en functioneel parket, alsmede ten aanzien van mandateren bevoegdheden officier van justitie in verbinding met art. 3, aanhef en onder e, Wet op de bijzondere opsporingsdiensten.

53. Bijvoorbeeld omdat er wordt aangeknoopt bij de woonplaats van de verdachte, terwijl die woonplaats in een andere arrondissement valt dan Amsterdam, Oost-Brabant, Overijssel of Rotterdam. De enkele omstandigheid dat de officier van justitie die de dagvaarding uitbrengt, is verbonden aan het functioneel parket, terwijl het feit valt onder de feiten ten aanzien waarvan het functioneel parket is belast met de vervolging, staat niet in de weg aan het aannemen van competentie op grond van de woonplaats.

54. Vgl. ook Kamerstukken // 2019/20, 35429, nr. 3, p. 7. Dat het EOM en het Nederlandse openbaar ministerie duidelijk van elkaar moeten worden onderscheiden, komt ook tot uitdrukking in Kamerstukken II 2019/20, 35429, nr. 3, p. 16-17. 


\subsection{Vervolging door het EOM bij} ambtsmisdrijven?

Een andere kwestie van een hoog theoretisch gehalte, die echter toch niet onbenoemd kan blijven, betreft de vervolging wegens ambtsdelicten. Als een lid van de Staten-Generaal, een minister of een staatssecretaris wordt vervolgd wegens een ambtsdelict, vindt die vervolging in eerste en enige instantie plaats bij de Hoge Raad. Daarbij geldt dat de opdracht tot vervolging wordt gegeven bij koninklijk besluit of bij een besluit van de Tweede Kamer, en dat die vervolging geschiedt door de procureur-generaal bij de Hoge Raad. Deze procedure is vastgelegd in (onder meer) artikel $76 \mathrm{Wet}$ RO en de Wet ministeriële verantwoordelijkheid en ambtsdelicten leden Staten-Generaal, ministers en staatssecretarissen. Van een ambtsmisdrijf is sprake als het gaat om een misdrijf in de zin van titel XXVIII van het Wetboek van Strafrecht, maar er kan ook sprake zijn van een ambtsdelict als een strafbaar feit wordt begaan onder één van de strafverzwarende omstandigheden zoals genoemd in artikel $44 \mathrm{Sr}^{55}$

Wanneer men in ogenschouw neemt welke strafbare feiten worden omschreven in Richtlijn $2017 / 1371,{ }^{56}$ is het niet ondenkbaar dat een ambtsdelict onder omstandigheden onder de bevoegdheid van het EOM valt. Als het EOM de vervolging op zich zou nemen, geldt dat de Hoge Raad de absoluut en relatief competente rechter is. Maar de vraag is uiteraard of zo'n vervolging zich goed laat denken, gelet op de bijzondere en specifieke procedure die in Nederland geldt voor de vervolging van een lid van de Staten-Generaal, een minister of een staatssecretaris wegens een ambtsdelict. Kan de gedelegeerde Europese aanklager, die op nationaal niveau officier van justitie is, dan de rol van de procureur-generaal overnemen? De Verordening staat daaraan op zich niet in de weg, maar artikel 144a lid 1 Wet RO wel. Daarin wordt bepaald dat alle bevoegdheden die naar Nederlands recht toekomen aan de officier van justitie, de advocaatgeneraal en het openbaar ministerie, toekomen aan de gedelegeerd Europese aanklager. Daarbij worden de bevoegdheden van de procureur-generaal niet genoemd. Een andere vraag is of een systeem waarin vervolging alleen plaatsvindt in opdracht, te verenigen is met het stelsel dat in de Verordening is gekozen voor de vervolging door het EOM. In de Verordening treft men over dergelijke exceptionele modaliteiten van vervolging geen specifieke bepalingen aan. Uiteraard kan men trachten aan de hand van wat wel in de Verordening wordt geregeld en verder op grond van het Unierecht een antwoord te vinden op die vragen. ${ }^{57} \mathrm{Ik}$ laat dat hier verder

55. Art. 3 lid 2 Wet ministeriële verantwoordelijkheid en ambtsdelicten leden Staten-Generaal, ministers en staatssecretarissen.

56. Aan de toelichting op wetsvoorstel 35160 waarmee Richtlijn $2017 / 1371$ is geïmplementeerd, valt te ontlenen dat door de Nederlandse wetgever is aangenomen dat de misdrijven van art. 177, 178, 225 lid 1 en 2, 227a, 227b, 323a, 363, 364, 364a, 420bis en 420ter Sr alsmede artikel 69 en 69a AWR onder de reikwijdte van die richtlijn vallen. Zie Kamerstukken I/ 2018/19, 35160, nr. 3, p. 3-6.

57. Mogelijk is hier art. 29 lid 1 Verordening van belang. Daarin wordt bepaald dat als een onderzoek van het EOM betrekking heeft op perso- rusten en volsta met de opmerking dat in het kader van de voorgenomen herziening van het stelsel van de vervolging bij ambtsmisdrijven nadere aandacht zou kunnen worden besteed aan de positie van het EOM. ${ }^{58}$

\subsection{Toetsing van de vervolgingsbeslissing}

Een volgend aandachtspunt betreft de toetsing van de vervolgingsbeslissing in de situatie dat de zaak voor de rechter wordt gebracht. Zoals aan de orde is gekomen, wordt de wijze waarop de vervolgingsbeslissing wordt genomen, geregeld in de Verordening. Dat betekent dat het nemen van die beslissing wordt genormeerd door het Unierecht. Tegelijkertijd is het stelsel van de Verordening erop gebaseerd dat de vervolging voor de nationale rechter plaatsvindt, waarbij er wordt vervolgd voor een feit dat in het nationale recht strafbaar is gesteld. Er vindt een strafrechtelijke procedure naar nationaal recht plaats, zij het dat de vervolgende instantie niet een nationale instantie is maar het EOM. Betekent dit dat de vervolgingsbeletselen die uit het nationale recht volgen, ook aan vervolging door het EOM in de weg kunnen staan? Artikel 42 lid 1 Verordening duidt erop dat deze vraag positief kan worden beantwoord. De beslissing om tot vervolging over te gaan kan immers worden aangemerkt als een procedurele handeling van het EOM die bedoeld is om rechtsgevolgen ten aanzien van derden te creëren, zodat het aan de nationale rechter is om die handeling te toetsen 'overeenkomstig de voorschriften en procedures in het nationale recht' ${ }^{59}$ Dat betekent dat de Nederlandse strafrechter de beslissing van het EOM kan toetsen aan de vervolgingsbeletselen die naar Nederlands recht gelden, tenzij - gelet op de voorrang van het Unierecht ${ }^{60}-$ zo'n beletsel in strijd zou komen met het Unierecht. ${ }^{61}$ De belangrijkste vervolgingsbelet-

nen die krachtens het nationale recht een voorrecht of immuniteit genieten dat/die een belemmering vormt voor een bepaald onderzoek, de Europese hoofdaanklager een gemotiveerd schriftelijk verzoek moet indienen tot opheffing van dat voorrecht of die immuniteit overeenkomstig de procedures die daarvoor in het nationale recht zijn vastgesteld. Wellicht kan hier als voorrecht gelden dat vervolging alleen plaatsvindt wanneer de opdracht tot vervolging wordt gegeven bij koninklijk besluit of bij een besluit van de Tweede Kamer.

58. Ik wijs erop dat recent het rapport is verschenen van de Commissie herziening wetgeving ambtsdelicten Kamerleden en bewindspersonen (Niet boven, maar in de wet, Den Haag 2021), waarin voorstellen worden gedaan om de huidige regeling op de schop te nemen. Aan het EOM wordt daarbij geen aandacht besteed.

59. Vgl. ook Geelhoed 2017, p. 91. De preambule bij de Verordening spreekt daarbij onder 87 van 'de procedurele handelingen van het EOM die vóór de tenlastelegging zijn vastgesteld'. Dat betekent m.i. niet dat de beslissing om tot dagvaarding over te gaan buiten het bereik van art. 42 lid 1 Verordening zou vallen. Ik begrijp de tekst van de preambule zo dat daarin tot uitdrukking wordt gebracht dat (ook) de handelingen voorafgaand aan de aanvang van het onderzoek ter terechtzitting kunnen worden getoetst. Dat de handelingen die daarna worden verricht, ook door de rechter kunnen worden beoordeeld, volgt al daaruit dat de procedure voor de rechter op grond van het nationale recht verloopt.

60. Zie ook art. 5 lid 3 Verordening: 'Ten aanzien van aangelegenheden die zowel in het nationale recht als in deze verordening zijn geregeld, gaat de verordening voor.'

61. Zie ook de preambule onder 88: 'Wanneer nationale rechterlijke instanties de wettigheid van die handelingen [procedurehandelingen van het EOM die bedoeld zijn om rechtsgevolgen ten aanzien van derden te creëren; $M B]$ toetsen, mogen zij dit doen op basis van het Unierecht, 
selen die het Nederlandse strafprocesrecht kent, treden overigens ook al naar voren in de sepotgronden die artikel 39 lid 1 Verordening noemt: het overlijden van de verdachte (of het ontbonden zijn van de verdachte rechtspersoon), immuniteit, verjaring en ne bis in idem. Wat dat betreft zijn er, hoewel de noemer een andere is, duidelijke overeenkomsten tussen het Unierecht en het Nederlandse strafprocesrecht.

Het vorenstaande sluit niet uit dat de beslissing van het EOM om tot vervolging over te gaan ook op specifiek Unierechtelijke gronden zal worden bestreden. Ik stip hier twee typen verweer aan. ${ }^{62}$ Allereerst kan dan worden gedacht aan een verweer van de strekking dat het EOM niet bevoegd is om tot vervolging over te gaan of dat het EOM op zich wel bevoegd is, maar er grond zou bestaan voor verwijzing van de zaak door het EOM naar de nationale autoriteiten. In paragraaf 3 is al an de orde gekomen dat de Verordening niet uitsluit dat de nationale rechter zich zal moeten uitspreken over de bevoegdheid van het EOM. Een verweer van de strekking dat niet het EOM, maar alleen het Nederlandse openbaar ministerie tot vervolging had mogen overgaan, noopt de rechter hiertoe. De vraag is dan wel wat de rechter precies toetst. Vanuit de Verordening bezien ligt het in de rede dat de rechter nagaat of de beslissing van het EOM om tot vervolging over te gaan in overeenstemming is met de voorschriften van artikel $22-25$ Verordening over de bevoegdheid van het EOM. Gelet op artikel 42 lid 2 Verordening kan de rechter, als daartoe aanleiding bestaat, prejudiciële vragen stellen over de uitleg van die voorschriften en ook over de geldigheid van procedurele handelingen van het EOM - waaronder ook de beslissing om tot vervolging over te gaan - voor zover die geldigheid op basis van het Unierecht ter discussie is gesteld. Een vraag die zich echter opdringt, is welk belang een verdachte heeft bij een bevoegdheidsverweer. Immers, het verweer kan slagen als komt vast te staan dat het EOM niet tot vervolging had mogen overgaan. Maar dat betekent dat de nationale autoriteiten, en dus het Nederlandse openbaar ministerie, bevoegd was om tot vervolging van het betreffende feit over te gaan. Tenzij in zo'n geval aannemelijk is dat het Nederlandse openbaar ministerie vervolging achterwege zou hebben gelaten, ${ }^{63}$ gaat het in de kern om niet meer dan de vraag of de verdachte door de kat of de hond wordt gebeten.

Een andere kwestie die onder omstandigheden in de strafzaak ter discussie kan worden gesteld, betreft de

met inbegrip van deze verordening, alsmede op basis van nationaal recht dat van toepassing is voor zover een aangelegenheid niet in deze verordening wordt behandeld.'

62. Buiten beschouwing blijft de toetsing van de vervolgingsbeslissing aan de beginselen van een goede procesorde. Zie daarover nader Geelhoed 2017. Ook ga ik niet in op de niet-ontvankelijkverklaring als rechtsgevolg na een vormverzuim, omdat de opsporing door het EOM - en in dat verband het mogelijke rechtsgevolg van een vormverzuim - in deze bijdrage niet aan de orde komt.

63. De invoering van het EOM doet er niet aan af dat het Nederlandse openbaar ministerie op grond van het opportuniteitsbeginsel beslist over vervolging. Vgl. Kamerstukken I/ 2019/20, 35429, nr. 6, p. 3-4. forumkeuze. De Verordening bevat diverse voorschriften voor de situatie waarin meerdere lidstaten rechtsmacht kunnen uitoefenen over het strafbare feit en waardoor het onderzoek naar en de vervolging van dat feit in verschillende lidstaten kan plaatsvinden. Artikel 26 lid 4 en 5 Verordening regelt daarbij - kort gezegd - aan welke gedelegeerde Europese aanklager een zaak wordt toegewezen, terwijl artikel 36 lid 3 en 4 Verordening de permanente kamer aanwijst als de instantie die beslist in welke lidstaat de vervolging plaatsvindt. Deze voorschriften laten een zekere interpretatie- en keuzeruimte, omdat daarin globale criteria worden gebruikt (zoals 'het zwaartepunt van de strafbare activiteit') en ook afwijkingen van de in dit stelsel gehanteerde hoofdregels worden toegelaten. Voor de verdachte kan het verschil maken in welke lidstaat de vervolging plaatsvindt. De vervolging en bestraffing vinden plaats overeenkomstig het nationale recht, waarbij het strafrechtstelsel van de ene lidstaat net gunstiger kan uitpakken dan dat van de andere lidstaat. In de preambule bij de Verordening is uitdrukkelijk opgenomen dat de procedurele handelingen 'betreffende de keuze van de lidstaat waarvan de rechtbanken de bevoegdheid tot het horen van de aanklager zullen hebben' door de nationale rechter kunnen worden getoetst. ${ }^{64}$ Ook hier geldt dat de Verordening niet nader voorschrijft hoe deze toetsing eruit zal moeten zien. Gelet op de interpretatie- en keuzeruimte die aan (de organen van) het EOM wordt gelaten bij het maken van de forumkeuze, ligt het voor de hand dat de nationale rechter de betreffende beslissing terughoudend zal toetsen. Ook hier geldt dat de rechter, als daartoe aanleiding bestaat, prejudiciële vragen kan stellen over de uitleg van de relevante voorschriften van de Verordening en ook over de geldigheid van procedurele handelingen van het EOM voor zover die geldigheid op basis van het Unierecht ter discussie is gesteld. ${ }^{65}$

\subsection{Hoger beroep en cassatie}

De gedelegeerde Europese aanklager heeft op grond van artikel 144a lid 1 Wet RO alle bevoegdheden die naar Nederlands recht toekomen aan de officier van justitie, de advocaat-generaal en het openbaar ministerie. Dit betekent onder meer dat, als een zaak door het EOM voor de Nederlandse strafrechter wordt vervolgd, de gedelegeerde Europese aanklager optreedt als officier van justitie bij de rechtbank. Wordt de zaak in hoger beroep behandeld, dan treedt de gedelegeerde Europese aanklager op als advocaat-generaal. Bestaat er daarna van de zijde van het EOM aanleiding om cassatieberoep in te stellen, dan is het wederom de gedelegeerde Europese aanklager die dat beroep zal instellen en een cassatieschriftuur zal indienen. Hierdoor kan zich - in aanmerking genomen dat Nederland (vooralsnog) twee

64. Preambule onder 87.

65. Zie uitvoerig over de forumkeuze en de toetsingsmogelijkheden M. Luchtman, 'Forum choice and judicial review under the EPPO's legislative framework', in: W. Geelhoed e.a. (red.), Shifting perspectives on the European Public Prosecutor's Office, Den Haag: Asser Press 2018, p. 155-170. 
gedelegeerde Europese aanklagers kent - eenvoudig de situatie voordoen dat één functionaris van het EOM in drie instanties optreedt. ${ }^{66}$ Dit wijkt af van het Nederlandse stelsel, waarin het openbaar ministerie in de regel in elke instantie door een andere functionaris wordt vertegenwoordigd. Zo'n stelsel bevordert collegiale intervisie, kan ook in zekere zin fungeren als correctiemechanisme $^{67}$ en maakt specialisatie mogelijk. Er is niet voorzien in de mogelijkheid dat leden van het Nederlandse openbaar ministerie optreden in naam van de gedelegeerde Europese aanklager, al is het wel toegestaan dat bijstand en ondersteuning wordt verleend aan de gedelegeerde Europese aanklager. ${ }^{68}$ Dat kan nuttig zijn, bijvoorbeeld als het gaat om het voeren van de cassatieprocedure.

In artikel 36 lid 7 Verordening wordt bepaald dat de beslissing over het al dan niet instellen van een rechtsmiddel niet wordt genomen door de gedelegeerde Europese aanklager, maar door de permanente kamer. ${ }^{69} \mathrm{De}$ gedelegeerde Europese aanklager is wel bevoegd om beroep in stellen als dat nodig is gelet op de termijnen die in het nationale recht gelden, maar dat kan ertoe leiden dat de permanente kamer de opdracht geeft dat beroep in te trekken. Ik begrijp deze regeling zo dat deze ziet op de verhouding tussen de permanente kamer en de gedelegeerde Europese aanklager. Dat betekent dat de beslissing van de permanente kamer om beroep in te stellen dan wel een ingesteld beroep in te trekken eerst effect heeft als de gedelegeerde Europese aanklager in overeenstemming met het nationale recht de daartoe noodzakelijke formaliteiten heeft vervuld.

\section{Afronding}

Aan het begin van deze bijdrage is opgemerkt dat de constructie waarin het EOM zaken voor de nationale strafrechter vervolgt en waarbij de gedelegeerde Europese aanklager alle bevoegdheden van een lid van het nationale openbaar ministerie uitoefent, de charme van de eenvoud heeft omdat op deze wijze voor het optreden van het EOM in de deelnemende lidstaten gebruik wordt gemaakt van de bestaande juridische infrastructuur. Maar het gaat daarbij wel om een verraderlijke eenvoud, want de combinatie van een verordening die de organisatie van en de besluitvormingsstructuur binnen het EOM regelt, en enkele algemene wettelijke bepalingen die de poort openen voor het EOM om overeenkomstig het nationale recht tot vervolging over te gaan, levert nog geen sluitend stelsel op. Er laten zich verschillende vraagpunten aanwijzen die illustreren dat op onderdelen aanvullende normering gewenst of noodzakelijk is. Die aanvullende normering zal eerst en vooral door de rechter moeten worden gevonden en geboden. Gelet op de regeling van artikel 42 Verordening ligt die taak primair bij de nationale rechter. Of beter gezegd: bij de nationale rechters van alle deelnemende lidstaten. Daarin ligt nog een uitdaging besloten. In deze bijdrage is naar voren gekomen dat de Verordening op tal van punten nog weinig houvast biedt voor de beantwoording van vragen rondom het vervolgingsrecht van het EOM. Mede daardoor dreigt het risico dat de diverse vragen, nu de deelnemende lidstaten een eigen strafrechtstelsel kennen met specifieke kenmerken, op verschillende wijzen zullen worden beantwoord. Het systeem van prejudiciële vragen zal daarbij moeten waarborgen dat de voorschriften van de Verordening en andere relevante bepalingen van Unierecht uniform worden uitgelegd.

66. Op een dergelijke verwevenheid van rollen is ook al gewezen in het kader van de beklagprocedure van art. 12 Sv (zie par. 4.2)

67. Vgl. art. 453 lid 2 Sv, op grond waarvan een advocaat-generaal het door de officier van justitie ingestelde hoger beroep kan intrekken.

68. Art. 5 lid 6 Verordening.

69. Art. 36 lid 7 Verordening schrijft eenzelfde procedure voor de situatie waarin de gedelegeerde Europese aanklager in de strafzaak niet-ontvankelijkverklaring van de zaak wil vorderen. 